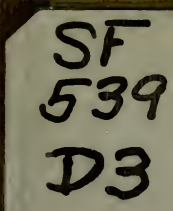

\title{
UC-NRLF
}

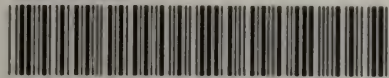

B 4275239

\section{SEES-WAX :}

ITS

Eromomira etses ano Comberston into fHomen.

BY

\section{J. DENNLER,}

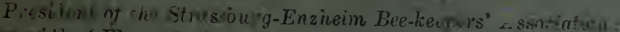

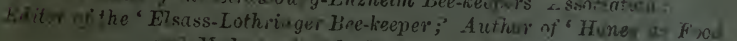
nes Viedicine,' and 'Horley and its E'ses.'

TRANSLATED FROM THE GERMAN AND [SITED BY

I. W. COWAN, F.G.S., F.L.S., F.R. H.S., tro

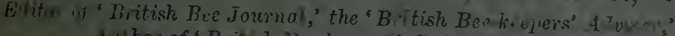
A thor of ' $B$, it ish boe keeqe, ' Guide Bnok?' \&.

Elllustiarco.

PUBLISHED BY

JUHN HUCKLE, KINGS LANGLEY, HERTS 1889. 

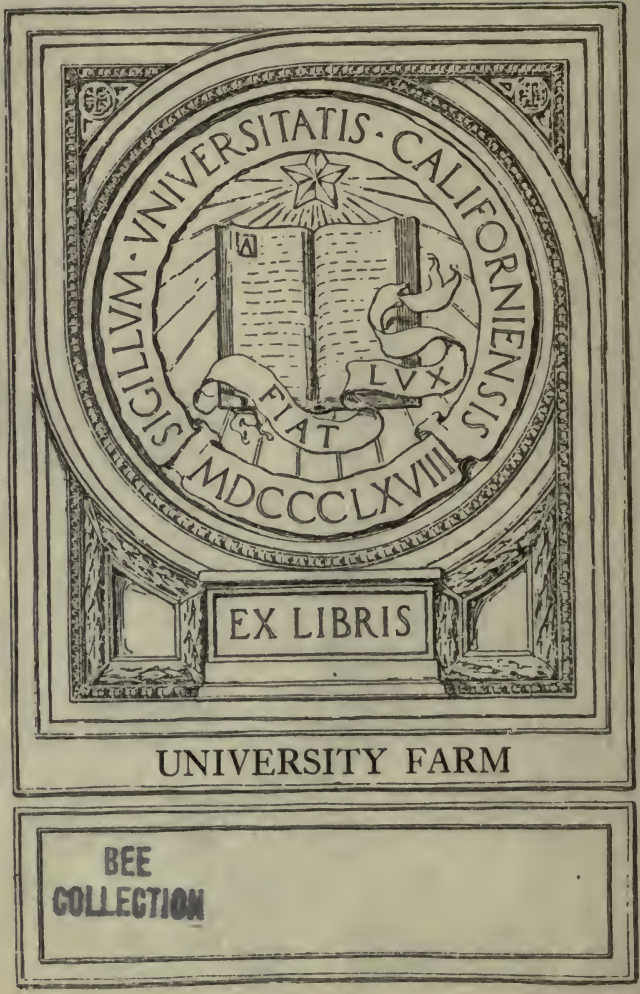

$8061^{\circ} 12$ NHF IVd I!IEO ' 0 07YJ07S sIOYeW

sorg proikes ләри!в 


\section{BEES-WAX :}

ITS

Eronomiral Plses and Conuersion into Atlonen.

BY

\section{J. DENNLER,}

President of the Strassburg-Enzheim Bee-keepers' Association ; Editor of the 'Elsass-Lothringer Bce-keeper;' Author of 'Honey as Food and Medicine,' and 'Honey and its Uses.'

TRANSLATED FROM THE GERMAN AND EDITED BY

T. W. COWAN, F.G.S., F.L.S., F.R.M.S., \&c. Editor of 'British Bce Journal,' the 'British Bee-keepers' Adviser,' Author of 'British Bee-leeper's' Guide Eook,' \&c.

\section{Ellustratex.}

PUBLISHED BY

JOHN HUCKLE, KINGS LANGLEY, HERTS. 1889. 
Digitized by the Internet Archive in 2007 with funding from Microsoft Corporation

http://www.archive.org/details/beeswaxitseconom00denrinch 


\section{BEES-WAX AND ITS ECONOMICAL USES.}

\section{H I S T O I C A L.}

BEES-WAX was known in ancient times. The Bible tells us of a land flowing with milk and honey; and where there was honey, there must also have been wax. Pliny speaks of white wax, and in the time of Dioscorides wax was rolled into sheets according to a method described by him.

At that time materials for lighting made from wax fetched a high price; they were used at divine service, and the consumption which was at first comparatively small, was afterwards increased by the spread of Christianity. The bleaching of wax was at that time carried on as an independent trade, and one sees how extensive it was by the fact that towards the end of the seventeenth century there were in Hamburg alone fourteen bleachinghouses for wax. It is certain that, with the exception of oil and tallow, as also of the common torch, no other material for lighting was known except wax, and this could only be used by very rich people.

Even princes who allowed themselves this luxury (as it was then held) were accounted extravagant. But, in addition to tapers, wax was used in still larger quantities for the manufacture of artificial flowers and fruits, which were much used as ornaments for rooms, for artificial flowers made of woven fabrics were not then known.

The Reformation dealt a heavy blow to the wax trade, and consequently bee-keeping also suffered, from the fact that the Evangelical Church did away with tapers at divine service.

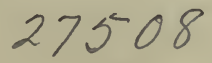


By the introduction of sugar bee-keeping was decrensed still more, and the production of wax was reduced to a minimum. As powerful competitors of wax, there appeared in commerce wax obtained from various plants and minerals, such as stearine, paraffine, ceresine, and others, which still further lowered the price of bees-wax.

Germany, has always produced a very much-prized wax for technical, medicinal, and artistic uses; so have also the various Austrian provinces and Switzerland. Turkey is said to produce the best of all known descriptions of wax. Turkish wax is also the dearest; usually of a bright orange colour. France produces a large quantity of splendid wax. Closely following the French comes the Spanish,in cakes of from 2 to $3 \mathrm{lbs}$. in weight. Italy also produces large quantities of excellent wax. Of the various kinds of wax other than European, the West Indian, Egyptian, and Barbary wax are highly prized.

\section{The Production of Wax.}

Bee-keepers, and amongst them Swammerdam, Maraldi, Réaumur, and others, were for a long time of opinion that bees collected wax directly from flower. (Swammerdam: Biblia Naturce; Maraldi : Observations sur les Abeilles; Mémoires de l'Acad. des Sciences, 1712; Réaumur: Histoire Nat. des Abeilles). But the experiments of Hunter have shown that the bee by no means plays so simple a part in the production of wax, for this great anatomist, so long ago as the year 1792, gave a description of the segments of the bee's abdomen, by which the wax is separated into small scales (Philos $p$ )h. Trans., 1712), an observation which Huber of Genera confirms in his Nouvelles Observations sur les Abeilles, II., chap. 1. Already in 1684 Martin John had made the same observation.*

* It is difficult to say who first discovered the scales of wax, but they were noticed and described by Herman C. Hornhostel, a Hanoverian pastor, in the Hamburg Library about 1745. A German farmer, a member of the Lusatian bee society, also noticed them in 1765 , and this fact was communicated to Bonnet by Willeim. In 1774 Thcrley mentioned them, and so did Wildman in 1779.-T. W. C 
Beeswax, then, is not found ready-made in nature, but is produced in the bee's body; it is like honey, an organic production, and not a mechanical or technical one. Wax is formed in the body of the working bee, of fluid honey, and pollen. But it is not formed involuntarily, as every well-nourished animal body forms fat, but voluntarily, viz., when the bees wish to form it, and when they have taken fluid honey, and pollen, in a larger quantity than they need for their own bodily nourishment, and the surplus is neither given as food to

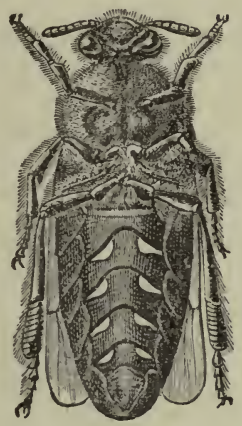

Fig. 1.-Wax-scales on under side of abdomen.

the brood, the queen, or the drones, but is retained, further digested, and allowed to pass into the bloodvessels, in order to be organically, chemically distilled there, and to exude as a kind of fatty matter by the segments of the abdomen.

The wax leaves the secreting glands in a fluid state, and solidifies in the form of small transparent white scales, five-cornered, shining like mother of pearl, in size about two square millimetres, such as are found in large numbers on the floor-boards of a strong colony when comb building.

When the bees want to build comb, they hang 
together in the form of a bunch of grapes, by which a certain amount of order is observed. The bees do not hang irregularly one upon the other by the hooklets of their feet, but the whole bunch is formed by the bees holding together in the form of a chain. The great heat generated in the cluster of bees facilitates the separation of the wax from their bodies (fig. 1).

Newly-built combs vary in colour from a light yellow to an orange red. It is remarkable that a light yellow wax comes from dark kinds of honey like, for instance, heather honey, and a dark orange red wax from white honey, as, for example, vetch honey.

This circumstance, which Mons. de Layens, a wellknown bee-keeper and author in France was the first to notice, led this sagacious inquirer to think that the colouring of the wax was probably due to pollen, and this was chemically proved to be the case by Dr. A. Von Planta, the famous Swiss chemist.

Beeswax consists of two different substances. It is a mixture of cerotic acid (cerin), which is soluble in alcohol, and of myricine, which is only slightly soluble in alcohol. Besides these constituents beeswax contains organic colouring matter, also other organic matters, which can be separated in the purifying. The colouring matter is best removed by bleaching in clear sunshine. Chemically pure wax is, when white, colourless and tasteless, and in thin scales is very transparent, shows a splintery fracture, and at $20^{\circ} \mathrm{C}$. assumes that peculiar lneadable condition which is qualified by the description of being 'wax-like.' The melting point of wax is very high, between $63^{\circ}$ and $64^{\circ} \mathrm{C}$, , and this is a good means of recognising the genuineness of the production, together with the specific gravity, which lies between 0.965 and 0.969 .

The elaboration of wax not only makes great claims on the vital powers of the bees, but also costs them, as well as the bee-keeper, much honey. It has been calculated that for one pound of wax, from ten to fifteen pounds of honey are required, without counting the loss of time caused in the building. Von Berlepsch makes 
the proportion from 13 to 1 , Dr. Dönhoff from $14 \frac{1}{3}$ to 1 , and Cowan estimates the production of wax at 20 to 1 . But $20 \mathrm{lbs}$. of honey are worth 20 shillings, while for $1 \mathrm{lb}$. of wax one gets only 2 shillings.* The intelligent bee-keeper will see by these figures how valuable good combs are.

It is to the interest of every bee-keeper to try and protect his combs from the ravages of the wax-moths. These moths, of which there is a large and a small kind (Galleria cereana, Galleria alvearia) lay their eggs in the combs, or in the débris of the bee-hives. It is the larvæ which hatch from these eggs that spin webs round the comb and eat it. It is specially the large kind of larvæ that very much increase the difficulty of preserving the combs. The right way to get rid of them, or to kill them, consists in hanging up your frames of comb in hermetically sealed boxes, and in warm weather to burn a piece of sulphur in it every three or four weeks. The ravages of the wax-moth may also be prevented by hanging up the combs and exposing them to a current of air.

\section{Comb Foundation.}

There came a time when the bees did not satisfy the needs of the bee-keeper as regards accuracy in building: the rows of comb, and their habit of beginning to build their comb on the edges and the sides gave some beekeepers the idea of providing the centre of the under side of top bar with a sharply projecting strip of wood (Giebelhausen and Böttner). A line of wax was also recommended (Dr. Honert). The bees were to build regularly upon it. Sometimes they did, but more of ten they did not. 'Tongs were also prepared which made impressions of the cells on little pieces of wood (Wilde).

* Recent experiments of Mr. G. de Layens show that, under certain favourable conditions, bees may only consume $6.3 \mathrm{lbs}$. of honey to produce $1 \mathrm{lb}$. of comb ; so that at least 10 to $16 \mathrm{lbs}$. of honey may be reckoned as necessary under ordinary circumstances for the production of $1 \mathrm{lb}$. of comb.-T. W. C. 
Otto Schulz writes (History of Artificial Comb) that these methods succeeded in inducing bees to build straight by constant time-wasting manipulations, yet all one's hopes were not realised, and the vexation was especially great when the bee-keeper in the early springput in a frame provided with the impressions, and at the beginning of the construction perceived that principally drone-cells were being built.

The carpenter, Mehring, of Frankenthal in the Palatinate, was the first to conceive the idea of constructing a pair of plates of wood on which were engraved the impressions of the bases of the cells, with which he pressed out of wax-sheets the first foundations of the comb. Dümmler in Homburg, Kunz in Jägendorf, Sand in Gundau, Peter Jacob in Fraubrunnen in Switzerland, perfected the ingenious discovery, and soon furnished very useful foundations. But it was Otto Schulz, of Buckow, who, later on, brought the artificial combs to a perfection hitherto unattained.* Since then he has never been unfaithful to his principles, viz.: to furnish a perfect product at a low price and in large quantities. That this undertaking has grown in the hands of the 'Bee-lord' (literally the bee-village-magistrate), as our manufacturer is called in the bee-world, is to be seen by the fact that his business increases every year, and that, in 1885, he produced and despatched about 18,000 kilogrammes (a kilogramme $=2 \frac{1}{5}$ lbs.). $\dagger$ Competition was not wanting. Comb foundation manufactories have shot up like mushrooms from the ground in the two last de-

* Some of the best machines have been made in America, and Mr. Root was one of the first in that country to popularise the use of foundation, and to construct a practical machine for its production. Amongst the most popular machines the best are, the Vandervoort, Dunham, and Root, but none of these excel those made in England by A. Godman.-T. W. C.

† These figures have been considerably exceeded by Messrs. Dadant \& Son, who in 1887 produced and sold 57,831 lbs. of comb foundation, notwithstanding that the season was a bad one in America. - T. W. C. 
cades. Of those best known we may mention in Germany, Friedrich in Griefswald, Hermann Bruder in Waldshut (Baden), A. Herlikofer in Gmünd (Würtemberg), Adam Wendler in Aschaffenburg (Bavaria), Weyell and Breidecker in Sauer-Schwafbenheim (in Khenish Hesse), Voight in Bahn (Pomerania). In Austrian Hungary, Anton John Wagner in Vienna, Joseph Ludwig, the Master Carpenter of Moravian Bee-keepers' Union in Brïn ; in Switzerland, Siegwart in Altdorf (Uri), Hermann Brogle in Siesseln; in England, Messrs. Abbott of Southall, London ; * in America, Ch. Dadant of Hamilton (Illinois).

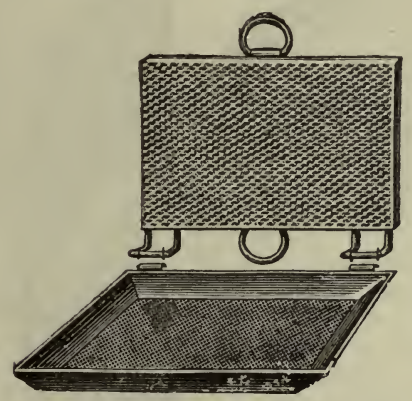

FIG. 2.-Rietsche Foundation Presser.

By the recent improvement of the presser, bee-keepers are enabled to press for themselves the foundations they require, instead of selling their wax at ridiculously low prices. Rietsche in Bieberach (Baden) supplies such presses, Fig. 2, as well as Hermann Greve, in Neu-Bradenburg (Mecklenburg), and Ihring and Fahrenholz, in Berlin. The Italian hand-presser, Fig. 3, of Guazzoni, who also

* Besides Messrs. Abbott in England there are Messrs. Blow, Neighbour, Baldwin, Howard, and Stothard, who manufacture comb foundation $-\mathrm{T}$ W. C. 
10

BEESWAX AND ITS ECONOMICAL USES.

invented the wax-smelter, Fig. 4, is a very practical appliance. Of course in the home manufacture of foundation

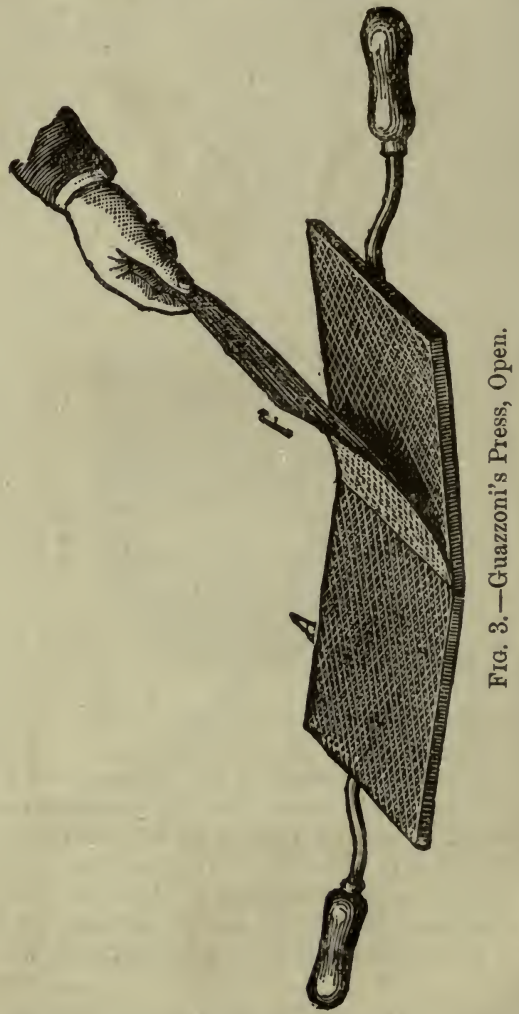

one must not expect first-class goods, for every trade needs long practice, and a bee-keeper will seldom attain per- 
BEES-WAX AND ITS ECONOMICAL USES.

fection if he has only to produce the foundation be requires for his own use.

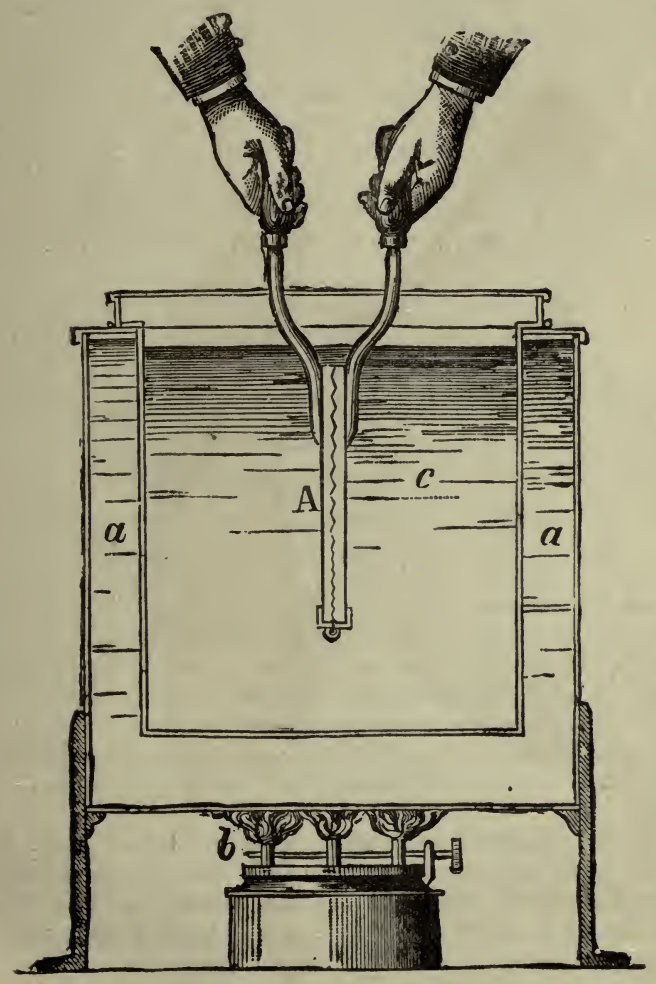

Fro. 4.-Guazzoni's Wax Smelter. 


\section{Wax Extraction.}

By the invention of the moveable comb hive "and honey extractor the production of wax has sunk to the minimum. The bee-keeper who uses moveable comb. hives only allows his bees to build such combs as may be required for brood and honey. The combs designed for the latter never.wear out, and can be used not only ten, twenty, or fifty, but even fifty plus fifty years and more, as the damage caused by the extracting is always repaired by the bees. Brood-comb, on the contrary, must from time to time be melted down and replaced by new. An apiary of twenty to thirty frame hives will only

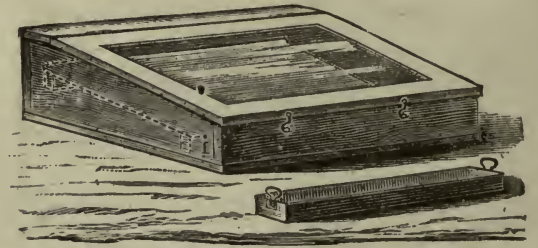

Fig. 5.-Solar Wax-extractor.

yield very small quantities of wax. It is therefore all the more necessary carefully to collect all refuse wax in order to melt it down. The most suitable apparatus for this is the solar wax-extractor, which consists of a little wooden box with a moveable glass cover (see Fig. 5). Inside there is an inclined sheet of tin (marked by dotted lines), upon which the combs to be molted are laid.

If the extractor is placed in a very sunny place the wax melts and flows into the little tin trough, which is placed under the tin plate at $i$ in illustration. The refuse remaining is taken away when the molten wax ceases to flow.

Those who wish to melt small quantities of wax without an extractor should put them in a loose bag, place a few laths in a copper, so that the bag shall not touch 
the bottom, weight it with a stone, pour water over it, and then let the mass boil. The wax melts, rises to the surface of the water, and is taken off after it has become cold. For large quantities the wax-press (see fig.6)

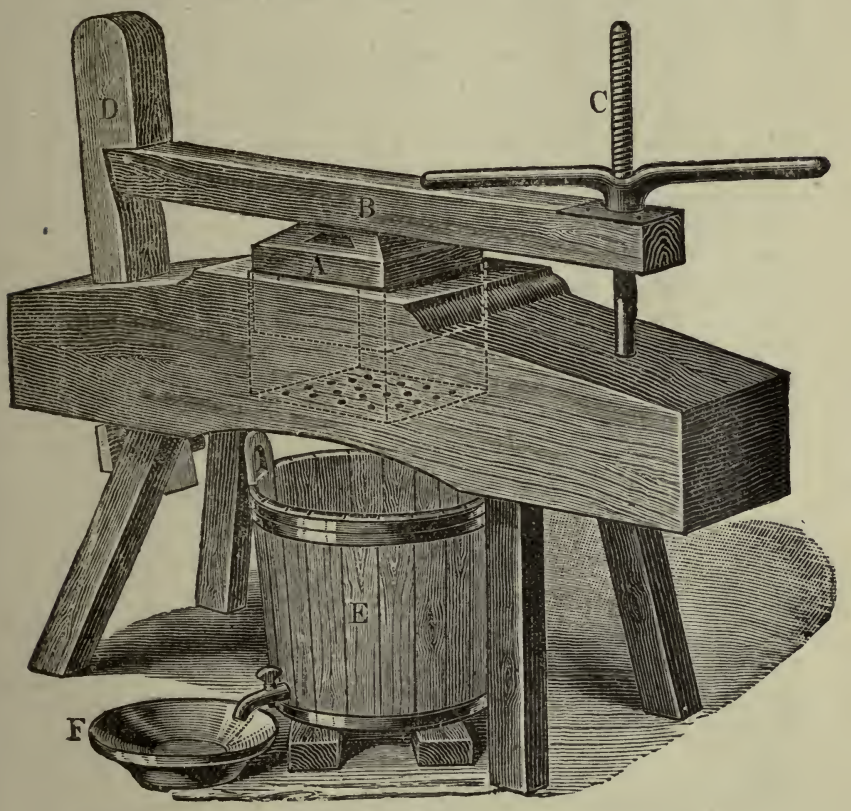

Fig. 6.-Wax Press.

is suitable, and is used by the Heath bee-keepers in northern Germany. The illustration is so exact that it needs little description to make one understand the handling of it.

The bar B presses the block of wood A upon the bag containing the wax, and this flows with the water into 
the pail E. As soon as the latter is full, the tap is opened, the water then flows into the basin F, and is put back into the wax-kettle, that the wax may remain boiling, which would not happen if cold water were added. When the pressing is finished the water is allowed to run away.

In order to free the so-called raw wax, obtained in this way, from any impurities which it may still contain, it is melted once more in a copper half-filled with water, well stirred for a few minutes, and then left for about two hours over a moderate fire, not being allowed to boil. When the kettle is taken off the fire, the scum is taken off and the cake of wax allowed to get hard. The impurities in the wax have now partly sunk to the bottom of the kettle and are partly attached to the under side of the cake, from which they are scraped with a knife. Many bee-keepers repeat this melting a second time, and thus are able to get a better and purer wax.

The Adulteration and Analysis of Wax.

It does not redound to the credit of the present age that it is often called the century of adulteration, but this is not to be wondered at. The evil spirit of adulteration has crept into all branches of handicraft, so that now the adjective 'pure' can be applied to only very few articles of commerce. Of late attempts have been made to supplant the honey of our bees by any available substitutes, and it is no better with regard to wax. Tallow, stearin, vegetable wax, earth wax (ozokerit), and other inferior linds of wax are mixed with bees-wax, and are sold as such in the trade.

'The adulterations of wax,' writes Dr. A. von Planta, 'are so difficult to detect, that it is scarcely practicable for those who are not experts. Pure bees-wax melts a,t $63^{\circ} .5 \mathrm{C}$. I have tried the melting point of twenty-five such pure specimens of bees-wax obtained from different countries, and it entirely agreed with that stated above.' But since adulteration has been effected with earth-wax, paraffine, and animal fats, the melting point does not 
provide sufficient evidence. Otherwise this method would have furnished a good test for those who are not experts.

There remains, therefore, no other way but to take the wax to a chemist, who will find out the quantity of cerotic acid and the non-volatile fatty acids, and such an analysis will provide a much safer criterion with regard to the adulteration.

The following simple tests, however, have often been found useful:- $(a$.) When wax is chewed there should be no unpleasant taste, and it should not stick to the teeth. If wax is adulterated with other ingredients the taste alone will detect them. If it sticks to the teeth the admixture of resin can be assumed. (b.) Pure beeswax from that adulterated is also determined by first bumping quickly on a hot iron plate a small bit of beeswax which is known to be pure. The smell given off is noticed. Then the piece of wax to be examined is burnt in the same way. If it contains ceresine a disagreeable, fatty, white smoke is given off, which differs the more from the smell of wax the more ceresine there is mixed with it. This is a simple way of testing the purity of purchased comb foundation.

\section{The Enployment of Wax for Economical Purposes.}

Beeswax, on account of itsilluminating powers, is used for the manufacture of candles and wax-tapers. Also, on account of its tenacity and flexibility, firmness and high melting point, it is indispensable in the great in.dustry of making wax figures and for modelling. Wax renders us important services also in house-keeping. In the following we have some useful recipes:-

\section{(a.) Sewing War.}

The beeswax is made up into little round balls and gives stiffness and smoothness to sewing thread. 


\section{(b.) Grafting Wax.}

Melt together one part of yellow wax, two parts of rosin, one part of turpentine, and a little lard. Let it get cool, and roll the mass out on a slab into sticks. This is the warm-melting grafting wax. At the present time cold grafting wax, recommended by Dr. Lucas, is often used, and this is prepared from rosin and spirit.

\section{(c.) Furniture Polish.}

Nelt two parts of wax, and stir into it, after it is taken off the fire, one part of turpentine.

\section{(d.) Wax Floor Polish.}

Mix 200 grammes of potash and 200 grammes of water, heat to boiling point, and gradually add while stirring 400 grammes of yellow wax. After this has been boiled up again, pour in 900 grammes of water, and heat until a milky fluid results. This is useful for polishing furniture and floors. (Els.-Loth. Bee-keeper.)

\section{(e.) Waterproof Packing Paper.}

Take twenty-four parts of blue soap and four parts of white soap, fifteen parts of wax, and boil in 120 parts of water. Dip the packing paper into it, let it well soak, and hang up over a string to dry.

\section{(f.) Leather Grease.}

For the preparation of this, mix $1 \frac{1}{2}$ lbs. of pure yellow wax in $1 \frac{1}{2}$ lbs. of oil of turpentine, $1 \frac{1}{2} \mathrm{lbs}$. of castor oil, $12 \frac{1}{2}$ lbs. of linseed oil, and $1 \frac{1}{2} \mathrm{lbs}$. of tar, and let the whole be thoroughly well mixed. By occasional applications from time to time (about every six months) harness is protected by this grease from the influence of air, heat, perspiration, and all moisture.

\section{(g.) Wax Dubbing for making Boots Waterproof}

Is prepared by melting together $6 \frac{1}{2}$ parts of yellow wax, $26 \frac{1}{2}$ parts of mutton fat, $6 \frac{1}{2}$ parts of thick turpentine, $6 \frac{1}{2}$ parts of olive oil, and 13 parts of lard, and stirring 
into this 5 parts of well-heated lampblack. The mas 3 is then poured into little wooden boxes. The dubbing is warmed and rubbed in with the fingers. The hard leather is softened, and becomes perfectly water-proof.

\section{(h.) Removing Crucks in Horses' Hoofs.}

Wax and honey in equal parts are melted together over a slow fire, and thoroughly mixed. It is used in this way: the hoof having been thoroughly cleansed with tepid water the above mixture is well rubbed in with a brush. After several applications the fissures and cracks disappear, and the hoof regains its softness.

\section{Uses of Wax in Medicine.}

(a.) Remedies for Coughs, Expectoration, Erysipelas.

Breathe the vapour of wax which is melted on a hot iron or a brazier of charcoal.

\section{(b.) Healing Salve.}

Honey, oil, and wax melted together are made into a salve which hastens the healing of old wounds and ulcers.

\section{(c.) Marigold-flower Plasters for Wounds.}

From marigold flowers a plaster can be made by bruising the flowers and the stalks and mixing them with as much lard as will cover them, allowing the mass to boil over a moderate fire for an hour, and then squeezing it through a cloth. The liquid that is pressed out is put on the fire again, and as much yellow wax added as will make it of the consistency of a plaster. If less wax is used, marigold flower salve is obtained. Both preparations are useful for all kinds of wounds.

\section{(d.) Remedy for Diarrhoca.}

In France the following remedy is frequently found of 
use:--Scoop out the core of a quince, fill it with hot wax, and let it roast gently and for a long time by the fire. This is eaten fasting for three consecutive mornings.

(e.) Salve for Wounds after Removal of Warts.

Prepare a salve of white wax and fresh unsalted butter in equal parts, and mix a little white wine with it.

\section{(f.) Salve for Burns.}

A mixture of wax and linseed oil malres an excellent plaster for burns. Stahl's burn-salve is made of equal parts of butter and yellow wax.

\section{(g.) Corn Plaster.}

For corns a good plaster is made of wax, tallow, and a little verdigris.

\section{(h.) Tooth-stopping.}

Tooth-stopping is prepared by melting 3 parts of pure white wax with $3 \frac{1}{2}$ parts of mastic, adding a few drops of oil of peppermint, and making it into pills on a marble slab. The hollow teeth are filled with these so that food may not lodge in them and irritate the nerres.

(i.) Wax Salve for Slin Diseases.

5 parts of white wax, 5 parts of spermaceti, 5 parts of sweet almond oil, are melted together in an enamelled saucepan, poured out into little paper boxes, and when cold are cut up into small tablets.

\section{Cosmetic Specialties.}

(a.) Glycerine Wax Balsam.

2 parts of white wax, 2 parts of spermaceti, 8 parts of sweet almond oil, 4 parts of glycerine, $\frac{1}{8}$ part of attar 
of roses, are carefully melted together in an enamelled saucepan over a slow fire, stirred until cold, and put into glass jars.

\section{(b.) Crème Céleste.}

$1 \frac{1}{2}$ parts of white wax, 3 parts of spermaceti, 3 parts of sweet almond oil, are melted together in a porcelain dish over a water bath, and when cold 2 parts of rose water are stirred in.

\section{(c.) Cold Cream}

Is used to keep the skin delicate and soft. It is prepared by rubbing together in a water bath 1 part of white wax, 2 parts of spermaceti, 8 parts of sweet almond oil, and 5 parts of rose water.

\section{(d.) Cosmétique.}

Melt in a porcelain dish over a water bath 500 grammes of yellow wax, and 125 grammes of white soap, take it from the fire, let it cool, and before the mass has set stir in 5 grammes of bergamot and 1 gramme of Peruvian balsam. It is rolled into small sticks on a glass or marble slab, and these are corered with paper. 
RETURN TO the circulation desk of any University of California Library or to the

NORTHERN REGIONAL LIBRARY FACILITY Bldg. 400, Richmond. Field Station University of Californta Richmond, CA 94804-4698

ALL BOOKS MAY BE RECALLED AFTER 7 DAYS

- 2-month loans may be renewed by calling (510) 642-6753

- 1-year loans may be recharged by bringing books to NRLF

- Renewals and recharges may be made 4 days prior to due date.

DUE AS STAMPED BELOW

DCT 072000 


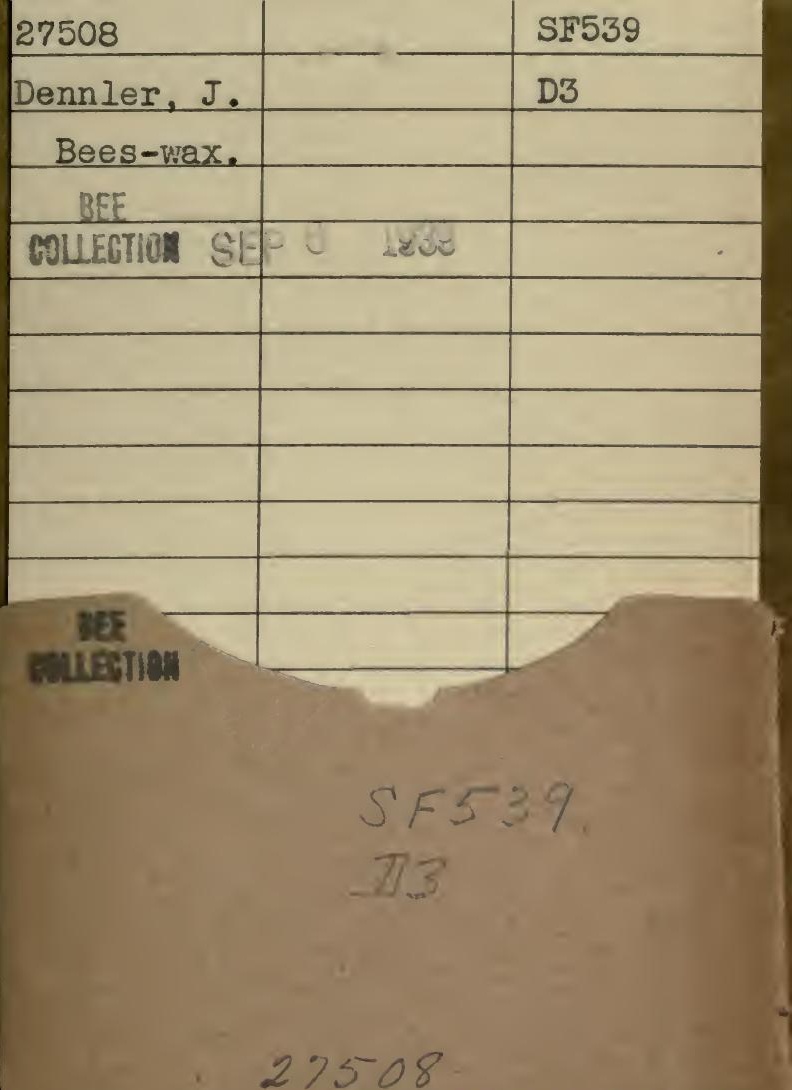

LIBRARY, BRANCH OF THE COLLEGE OF AGRICULTURE, DAVIS

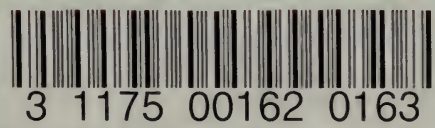


